\title{
Chronic exposure to leucine in vitro induces $\beta$-cell dysfunction in INS-1E cells and mouse islets
}

\author{
Zhenping Liư ${ }^{1,3}$, Per Bendix Jeppesen ${ }^{1}$, Søren Gregersen ${ }^{1}$, Lotte Bach Larsen ${ }^{2}$ and Kjeld Hermansen ${ }^{1}$ \\ ${ }^{1}$ Department of Medicine and Endocrinology (MEA), Aarhus University Hospital, Aarhus Sygehus THG, Tage-Hansens Gade 2, DK-8000 Aarhus C, Denmark \\ ${ }^{2}$ Department of Food Science, Faculty of Agricultural Sciences, Aarhus University, DK-8230 Tjele, Denmark \\ ${ }^{3}$ Department of Endocrinology, PLA 309 Hospital, Beijing 100091, People's Republic of China \\ (Correspondence should be addressed to Z Liu at Department of Medicine and Endocrinology (MEA), Aarhus University Hospital; Email: zhenping.liu@ki.au.dk)
}

\begin{abstract}
Chronic hyperglycemia and hyperlipidemia cause deleterious effects on $\beta$-cell function. Interestingly, increased circulating amino acid (AA) levels are also a characteristic of the prediabetic and diabetic state. The chronic effects of AAs on $\beta$-cell function remain to be determined. Isolated mouse islets and INS-1E cells were incubated with or without excess leucine. After $72 \mathrm{~h}$, leucine increased basal insulin secretion and impaired glucose-stimulated insulin secretion in both mouse islets and INS-1E cells, corroborating the existence of aminoacidotoxicity-induced $\beta$-cell dysfunction. This took place concomitantly with alterations in proteins and genes involved in insulin granule transport, trafficking (e.g. collapsin response mediator protein 2 and GTP-binding nuclear protein Ran), insulin signal transduction (proteasome

subunit $\alpha$ type 6), and the oxidative phosphorylation pathway (cytochrome $c$ oxidase). Leucine downregulated insulin 1 gene expression but upregulated pancreas duodenum homeobox 1 and insulin $2 \mathrm{mRNA}$ expressions. Importantly, cholesterol $(\mathrm{CH})$ accumulated in INS-1E cells concomitantly with upregulation of enzymes involved in $\mathrm{CH}$ biosynthesis (e.g. 3-hydroxy3-methylglutaryl-CoA reductase, mevalonate (diphospho) decarboxylase, and squalene epoxidase) and LDL receptor, whereas triglyceride content was decreased. Our findings indicate that chronic exposure to elevated levels of leucine may have detrimental effects on both $\beta$-cell function and insulin sensitivity. Aminoacidotoxicity may play a pathogenic role in the development of type 2 diabetes.

Journal of Endocrinology (2012) 215, 79-88
\end{abstract}

\section{Introduction}

Type 2 diabetes (T2D) involves both defective insulin secretion and insulin resistance (IR). In T2D, hyperglycemia and hyperlipidemia exert deleterious effects on $\beta$-cell function, referred to as glucotoxicity and lipotoxicity (Xiao et al. 2001, El-Assaad et al. 2010), with increased basal insulin secretion (BIS) and impaired glucose-stimulated insulin secretion (GSIS). Patients with impaired glucose tolerance (IGT) or in the early stage of T2D present with characteristic $\beta$-cell dysfunction (Ferrannini et al. 2003), but the nature of the primary $\beta$-cell defect is still elusive.

In an IR state, plasma concentrations of amino acids (AAs) are elevated, particularly leucine, isoleucine, valine, proline, and glutamine (Newgard et al. 2009). Thus, elevated levels of certain AAs are also a characteristic of the diabetic state and may play a pathogenic role in the development of T2D in addition to hyperglycemia and dyslipidemia.

Most AAs, including leucine, acutely stimulate insulin secretion from pancreatic $\beta$ cells in a dose- and glucosedependent manner (Liu et al. 2008), and leucine stimulates insulin secretion by serving as both a metabolic fuel and an allosteric activator of glutamate dehydrogenase
(Newsholme et al. 2006, MacDonald et al. 2008). Leucine and its transaminated product $\boldsymbol{\alpha}$-ketoisocaproate may also affect insulin secretion via direct inhibition of $\beta$-cell ATP-regulated potassium channel currents (Newsholme et al. 2006). Correspondingly, acute in vivo studies consistently revealed that additional leucine intake increased insulin secretion and reduced postprandial blood glucose (Kalogeropoulou et al. 2008). However, there are conflicting results on the longterm effects of leucine on $\beta$-cell function. Long-term exposure of pancreatic islets to high leucine levels has been shown to selectively impair GSIS, which is associated with a reduced ATP-to-ADP ratio (Anello et al. 2001). Moreover, Zhang et al. (2009) reported that chronic exposure to leucine downregulates the expression of pancreas duodenum homeobox $1(P d x 1)$, glucokinase $(G k(G c k))$, and glucose transporter type 2 in rat insulinoma $\beta$ cells, resulting in decreased insulin content and GSIS at high glucose. However, this was challenged by the observation that leucine upregulates the ATP synthase $\beta$ subunit $(A T P \beta)$ mRNA level in RIN5mf cells and increases GSIS, ATP, GCK, and ATP $\beta$ levels in rat and human islets (Yang et al. 2006). Conflicting results were also observed when rats were fed leucine orally for varying number of weeks. Mice given a high-fat diet with doubled 
dietary leucine intake were significantly more glucose tolerant and insulin sensitive than high-fat diet mice without additional leucine (Zhang et al. 2007). By contrast, Balage et al. (2011) observed that leucine-supplemented rats displayed IGT and had a significant increase in visceral adipose tissue.

Given such conflicting results on the actions of leucine, we wanted to elucidate the long-term actions of leucine on $\beta$-cell function in vitro. Here, we show that chronic exposure to excess leucine induces characteristic diabetic changes in $\beta$-cell function (i.e. increases BIS and hampers GSIS) and alters $\beta$-cell gene and protein expressions. We found that leucine-induced $\beta$-cell dysfunction is related to abnormal cholesterol $(\mathrm{CH})$ metabolism with corresponding accumulation of $\mathrm{CH}$ content, impaired oxidative phosphorylation (OxPhos), impaired insulin secretory granules (ISGs) transport, and trafficking.

\section{Materials and Methods}

\section{Reagents and buffers/solutions}

All chemicals were from Sigma-Aldrich if not stated otherwise. Modified Krebs-Ringer buffer (M-KRB) contained $(\mathrm{mM}) \mathrm{NaCl}, 125 ; \mathrm{KCl}, 5 \cdot 9 ; \mathrm{MgCl}_{2}, 1 \cdot 2$; $\mathrm{CaCl}_{2}, 1 \cdot 28 ; \mathrm{NaHCO}_{3}, 5 \cdot 0 ;$ and HEPES, 25; pH 7.4. SYTO 24 solution: $5 \mathrm{mM}$ SYTO 24 green fluorescent nucleic acid stain (Molecular Probes, Invitrogen, Eugene, OR, USA) dissolved in DMSO $(\geq 99.9 \%)$ to a final concentration of $0 \cdot 01 \mathrm{mM}$. Glycine-BSA buffer $(\mathrm{pH} 8 \cdot 8)$ contained glycine $100 \mathrm{mM}$ and $0 \cdot 25 \%$ BSA. 2D-lysis buffer contained $6 \mathrm{M}$ urea, $2 \mathrm{M}$ thiourea, $1.5 \%(\mathrm{w} / \mathrm{v})$ pharmalyte, $0 \cdot 8 \%(\mathrm{w} / \mathrm{v})$ 3-[(3-cholamidopropyl) dimethylammonio]1 -propanesulfonate, and $1 \%(\mathrm{w} / \mathrm{v})$ dithioerythritol in water. The rehydration buffer consisted of the same substances, in the same concentrations as the lysis buffer, but with extra pharmalyte $(5 \mu \mathrm{l} / \mathrm{ml})$.

\section{Animals}

Adult female NMRI mice (Bomholtgaard Breeding and Research Centre, Ry, Denmark) weighing 20-25 g were used. The animals were kept on a standard pellet diet and tap water ad libitum and a $12 \mathrm{~h}$ light: $12 \mathrm{~h}$ darkness cycle. The study was carried out in accordance with the guidelines of the Danish Council for Animal Experiments.

\section{Islet isolation}

Islets were isolated by the collagenase digestion technique (Lacy \& Kostianovsky 1967). In brief, the animals were anesthetized i.p. with pentobarbital sodium $(50 \mathrm{mg} / \mathrm{kg})$, and a midline laparotomy was performed. The pancreas was retrogradely filled with $3 \mathrm{ml}$ ice-cold Hanks Balanced Salt Solution (HBSS) supplemented with $0.3 \mathrm{mg} / \mathrm{ml}$ collagenase P (Boehringer Mannheim). The pancreas was removed, incubated for $19 \mathrm{~min}$ at $37^{\circ} \mathrm{C}$ in a water bath, and subsequently rinsed with ice-cold HBSS, after which the islets were handpicked under a stereomicroscope. The islets were incubated overnight at $37{ }^{\circ} \mathrm{C}$ and $95 \%$ normal atmosphere-5\% $\mathrm{CO}_{2}$ in $10 \mathrm{ml}$ RPMI 1640 containing $11.1 \mathrm{mM}$ glucose supplemented with $10 \% \mathrm{FBS}$, $2.06 \mathrm{mM}$ glutamine, $100 \mathrm{IU} / \mathrm{ml}$ penicillin $\mathrm{G}$, and $100 \mu \mathrm{g} / \mathrm{ml}$ streptomycin (all Gibco-BRL).

\section{Insulin secretion from islets}

After overnight incubation, mouse islets were incubated in RPMI 1640 with $11.1 \mathrm{mM}$ glucose in the presence of 1, 5, and $10 \mathrm{mM}$ leucine, respectively, the normal RPMI 1640 containing $0.38 \mathrm{mM}$ leucine as control (all the following experiments take $0.38 \mathrm{mM}$ leucine as control). After $72-\mathrm{h}$ leucine treatment, islets were rinsed once with M-KRB supplemented with $3.3 \mathrm{mM}$ glucose and $0.1 \%$ human serum albumin and preincubated for $30 \mathrm{~min}$ in $\mathrm{M}-\mathrm{KRB}$ at $37^{\circ} \mathrm{C}$. Consequently, a single islet was handpicked and incubated in $100 \mu \mathrm{M}$-KRB with $3 \cdot 3$ or $16 \cdot 7 \mathrm{mM}$ glucose. After $60 \mathrm{~min}$ of incubation in normal atmosphere at $37^{\circ} \mathrm{C}$, the medium $(50 \mu \mathrm{l})$ was collected and frozen for analysis of insulin.

\section{Cell culture}

INS-1E cells (generous gift from Prof. Claes B Wollheim, Geneva, Switzerland) were cultured in RPMI 1640 medium containing $11.1 \mathrm{mM}$ D-glucose and supplemented with $10 \% \mathrm{FBS}, 100 \mathrm{IU} / \mathrm{ml}$ penicillin, $100 \mu \mathrm{g} / \mathrm{ml}$ streptomycin, $10 \mathrm{mM}$ HEPES, $2 \mathrm{mM}$ L-glutamine, $1 \mathrm{mM}$ sodium pyruvate, and $50 \mu \mathrm{M}$ 2-mercaptoethanol, at $37^{\circ} \mathrm{C}$ in a humidified atmosphere containing 95\% air and 5\% $\mathrm{CO}_{2}$. The cells were passaged weekly.

\section{Insulin secretion from INS-1E cells}

The INS-1E cells were seeded $\left(3 \cdot 0 \times 10^{5}\right.$ cells/well $)$ onto 24-well Black Visiplate TC (Wallac Oy, Turku, Finland) plates in $1 \mathrm{ml}$ RPMI 1640. After adhering overnight, the cells were cultured in RPMI 1640 with $11.1 \mathrm{mM}$ glucose in the presence of $0 \cdot 38,1,5$, and $10 \mathrm{mM}$ leucine for $72 \mathrm{~h}$ in a humidified atmosphere $\left(5 \% \mathrm{CO}_{2} 95 \%\right.$ air at $\left.37^{\circ} \mathrm{C}\right)$. Afterward, the cells were preincubated with M-KRB supplemented with $3.3 \mathrm{mM}$ glucose and $0.1 \%$ human serum albumin for $30 \mathrm{~min}$ and then the cells were incubated in $1 \mathrm{ml} \mathrm{M-KRB} \mathrm{containing} 3 \cdot 3$ or $16.7 \mathrm{mM}$ glucose for $1 \mathrm{~h}$. Subsequently, supernatants $(300 \mu \mathrm{l})$ were collected, centrifuged, and $200 \mu \mathrm{l}$ were kept at $-20{ }^{\circ} \mathrm{C}$ for insulin analysis. After the secretion study, the cells were washed once with $1 \mathrm{ml} \mathrm{PBS}$ (Gibco), and the number of cells was estimated using nuclear staining with SYTO 24 reagent $(20 \mu \mathrm{l} /$ well $)$ and measured by FLUOstar Galaxy (BMG, Ramcon, Denmark). Unless otherwise stated, passage numbers between 60 and 82 were used. 
Insulin output of INS-1E cells

INS-1E cells were incubated and treated as earlier. For the insulin output study, incubation medium $(25 \mu \mathrm{l})$ was sampled after 24,48 , and $72 \mathrm{~h}$ and stored at $-20^{\circ} \mathrm{C}$ until insulin analysis.

\section{Insulin content of INS-1E cells}

The INS-1E cells were incubated and treated as earlier, but in six-well plates with a density of $1 \cdot 0 \times 10^{6}$ cells/well in $3 \mathrm{ml}$ RPMI 1640. After $72 \mathrm{~h}$, the cells were washed once with $2 \mathrm{ml}$ cold PBS and then $1 \mathrm{ml}$ glycine-BSA buffer was added. Cells were scratched and sonicated twice at $0{ }^{\circ} \mathrm{C}$ for $14 \mathrm{~s}$ (Branson Sonifier 250, Danbury, CT, USA). We took $250 \mu \mathrm{l}$ to evaluate the total protein with a detergent-compatible protein kit (Bio-Rad Laboratories) for calibration of insulin content. The remaining $750 \mu \mathrm{l}$ was centrifuged for $30 \mathrm{~min}$ at $21460 \mathrm{~g}$ and the supernatant was collected and frozen at $-20{ }^{\circ} \mathrm{C}$ for a later insulin assay.

\section{Insulin assay}

Insulin was analyzed by RIA using a guinea pig antiporcine insulin antibody (Novo Nordisk, Bagsvaerd, Denmark) and mono- ${ }^{125}$ I-(Tyr A14)-labeled human insulin (Novo Nordisk $\mathrm{A} / \mathrm{S}$ ) as tracer and rat insulin as standard (Novo Nordisk A/S). The separation of bound and free radioactivity was performed using ethanol. The intra- and interassay coefficients of variation were determined to be $<10 \%$.

\section{Determination of triglyceride and $\mathrm{CH}$ content}

INS-1E cells were plated at $3 \cdot 0 \times 10^{5}$ cells/well in $1 \mathrm{ml}$ of medium in 24-well Black Visiplate TC plates. The cells were allowed to adhere overnight and then incubated and treated as earlier. After $72 \mathrm{~h}$, the cells were washed once with $1 \mathrm{ml} \mathrm{PBS}$, and the number of cells was estimated as earlier. The medium was removed, and the cells were frozen for $1 \mathrm{~h}$ at $-80^{\circ} \mathrm{C}$. Subsequently, the cells were treated for $20 \mathrm{~min}$ with triglyceride (TG) reagents $(250 \mu \mathrm{l} /$ well, Roche) at room temperature. TG content was determined with a TG GPOPAP kit (Roche) and normalized to cell number. The recovery of TG was $\sim 90 \%$.

Correspondingly, cells were treated for $20 \mathrm{~min}$ with $\mathrm{CH}$ reagents $(250 \mu \mathrm{l} /$ well, Roche $)$ at room temperature. $\mathrm{CH}$ content was determined by a CH CHOD-PAP kit (Roche) and was normalized to cell number. The recovery of $\mathrm{CH}$ content was $\sim 90 \%$.

\section{${ }^{3} \mathrm{H}$-thymidine incorporation in INS-1E cells}

${ }^{3} \mathrm{H}$-thymidine incorporation was used to monitor INS-1E cell proliferation and DNA synthesis. Briefly, INS-1E cells $\left(4 \times 10^{4} /\right.$ well) were seeded in 96 -well isoplates (Wallac Oy) and cultured in RPMI 1640 with $11.1 \mathrm{mM}$ glucose and
$10 \%$ FBS. On the next day, the cells were incubated with 'starvation medium' (RPMI 1640 with $0.5 \mathrm{mM}$ glucose, $0 \cdot 1 \%$ BSA, without FBS) for $24 \mathrm{~h}$. The cells were then cultured for another $72 \mathrm{~h}$ in RPMI 1640 containing $0.5 \%$ BSA, $11.1 \mathrm{mM}$ glucose in the presence of $0.38,1,5$, and $10 \mathrm{mM}$ leucine, and $1 \mu \mathrm{Ci}$ [methyl- $\left.{ }^{3} \mathrm{H}\right]$ thymidine (Perkin Elmer, Wellesley, MA, USA). After $72 \mathrm{~h}$, the cells were washed twice in cold PBS and $200 \mu \mathrm{l}$ liquid scintillator was applied. The incorporated [methyl- $\left.{ }^{3} \mathrm{H}\right]$ thymidine was counted by a 1450 MicroBeta TRILUX (Wallac).

\section{The incidence of dead INS-1E cells}

INS-1E cells were seeded in 96-well Black Visiplate TC plates (Wallac Oy) at a density of $4 \times 10^{4}$ cells/well in $200 \mu \mathrm{l}$ medium, the cells were allowed to adhere overnight, and then treated and cultured with different concentrations of leucine as earlier. After $72 \mathrm{~h}$, the number of dead cells in each well was calculated using a fluorometric assay kit based on the cell lysis and staining method (Sakai et al. 2001; Cytotoxic Fluoro-test Wako; Wako Pure Chemical Industries, Osaka, Japan) in the FLUOstar Galaxy. A linear relationship was confirmed in advance between the viable cell density and fluorescence intensity.

\section{RNA extraction and $c D N A$ synthesis}

Three different passages of INS-1E cells were incubated in RPMI 1640 in the presence of 0.38 or $5 \mathrm{mM}$ leucine for $72 \mathrm{~h}$. The RNA of treated cells was extracted using the AllPrep RNA/Protein kit (Qiagen) according to the manufacturer's instructions (AllPrep RNA/Protein Handbook; Qiagen) on the QIAcube machine (Qiagen). RNA concentration and purity were determined by measuring the absorbance at 260 and $280 \mathrm{~nm}$ (NanoDrop ND-8000 u.v.-Vis Spectrophotometer, NanoDrop Technologies Wilmington, DE, USA). The RNA quality was evaluated by examining the $18 \mathrm{~s}$ and $28 \mathrm{~s}$ ribosomal band on a $1 \%$ nondenaturing agarose gel, stained with SYBR green.

RT was performed using the iScript cDNA synthesis kit (Bio-Rad Laboratories, Inc.) according to the manufacturer's instructions. We applied $1 \mu \mathrm{g}$ total RNA for each $20 \mu \mathrm{l}$ RT reaction.

\section{Quantitative RT-PCR}

RT-PCR was performed using an Applied Biosystems 7500 FAST PCR machine (Applied Biosystems). Predesigned TaqMan probes and primers with the following catalog numbers were obtained from Applied Biosystems: $P d x 1$ (Rn00755591_m1), the v-maf musculoaponeurotic fibrosarcoma oncogene homolog A (MafA, Rn00845206_s1), insulin 1 (Ins1, Rn02121433_g1), insulin 2 (Ins2, Rn01774648_g1), acetyl-CoA carboxylase $\alpha$ (Acc1 (Acaca), Rn00573474_m1), fatty acid synthase (Fasn, Rn01463548_m1), sterol-regulatory element binding factor 2 (Srebf2, Rn01306296_m1), 
3-hydroxy-3-methylglutaryl-CoA reductase (Hmgcr, Rn00565598_m1), mevalonate (diphospho) decarboxylase (Mvd, Rn00579216_m1), squalene epoxidase (Sqle, Rn00567532_m1), LDL receptor (Ldlr, Rn00598442_m1), cytochrome $c$ oxidase (Cox), subunit VIa, polypeptide 2 (Cox6a2, Rn00563091_g1), caspase-3 (Casp3, Rn00563902_m1), death-associated protein kinase 3 (Dapk3, Rn00574826_m1), Bcl2 modifying factor (Bmf, Rn00594968_m1), and eukaryotic 18S (Hs99999901_s1).

The RT-PCR mix contained $5 \mu \mathrm{l}$ of $2 \times$ TaqMan FAST Universal Master Mix (P/N 43660783, Applied Biosystems), $0.5 \mu \mathrm{l}$ of $20 \times$ TaqMan Assay/probe (Applied Biosystems),

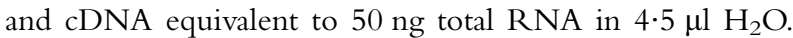
The thermal FAST cycle program was one cycle at $95{ }^{\circ} \mathrm{C}$ for $20 \mathrm{~s}, 40$ cycles at $95^{\circ} \mathrm{C}$ for $3 \mathrm{~s}$, and $60^{\circ} \mathrm{C}$ for $30 \mathrm{~s}$. Each PCR sample was performed in six repeats, and gene expressions were normalized to eukaryotic $18 \mathrm{~S}$ expression. All assays were carried out in 96-well plates with an optical adhesive cover (P/N 4346906 and P/N 4311971, Applied Biosystems). We used the $2^{-\Delta \Delta C T}$ method to calculate the relative gene expression (Pfaffl 2001). No template controls and no amplification controls were included for each gene as negative controls.

\section{INS-1E cell growth and lysis for proteomics}

Protein from three different passages of INS-1E cells was extracted at the same time as RNA was purified on the QIAcube machine. We took two samples every time for each condition; as a result, there were six replicates of each treatment used for proteomics. The protein content of the cell suspensions was analyzed by the Bradford assay (Bio-Rad). In order to obtain sufficient protein concentration of the cell suspensions, the samples were precipitated with addition of $250 \mu \mathrm{l} 24 \%$ trichloroacetic acid at $4{ }^{\circ} \mathrm{C}$ and left to precipitate for $30 \mathrm{~min}$ at $0{ }^{\circ} \mathrm{C}$, followed by centrifugation at $6000 \mathrm{~g}$ at $0{ }^{\circ} \mathrm{C}$ for $10 \mathrm{~min}$. The supernatant was removed, the protein pellet was washed twice by addition of $500 \mu \mathrm{l}$ acetone at $0{ }^{\circ} \mathrm{C}$, and centrifuged as described between each washing step. The protein pellets were kept at $-80{ }^{\circ} \mathrm{C}$ for proteomic analysis.

Proteomic analyses The 2-dimensional gel electrophoresis (2-DGE) analysis was performed essentially as described earlier (Young et al. 2010). Briefly, the stored protein pellets were thawed and solubilized in $250 \mu \mathrm{l}$ of $2 \mathrm{D}$ lysis buffer and subsequently tenfold in Millipore water. Based on protein determination using the Bradford assay, a sample volume corresponding to $100 \mu \mathrm{g}$ protein was applied to each gel. The 12 lysed cell samples were analyzed in a single 2-DGE gel set consisting of six gels representing either control INS-1E cells or treated with leucine, respectively, as described earlier using $11 \mathrm{~cm}$ IPG strips $(\mathrm{pH} \mathrm{5-8)}$ for the first dimension and $12.5 \%$ Criterion gels (Bio-Rad) for the second dimension. Analytical gels were stained with Flamingo Pink (Bio-Rad) and scanned using a Molecular Imager FX (Bio-Rad). Images were analyzed with PDQuest (Bio-Rad). Gels for spot identification were stained with colloid Coomassie Blue R-250 (Kang et al. 2002). In-gel digestion for peptide mass fingerprinting, desalting, and concentration of protein spots, identification of MFGM proteins by matrix-assisted laser desorption ionization-time of flight mass spectrometry, and image analysis was performed as described earlier (Larsen et al. 2010).

\section{Statistical analysis}

Data are presented as mean \pm s.E.M. We compared groups using one-way ANOVA; we also performed statistical analysis using the unpaired two-tailed Student's $t$-test with unequal

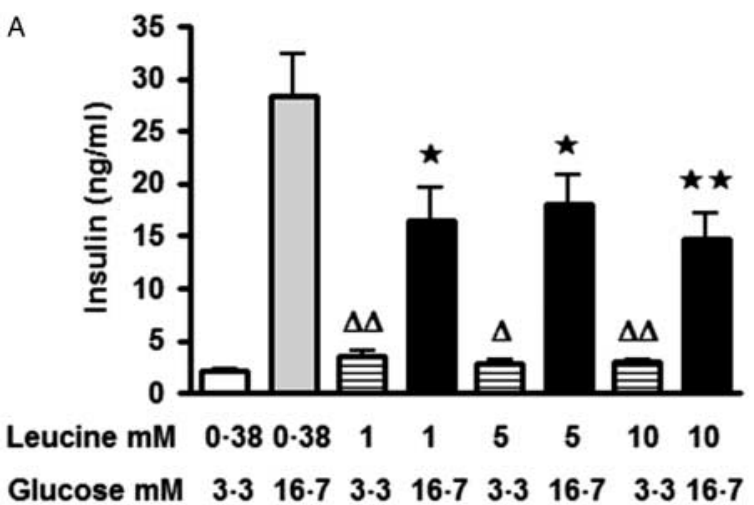

B

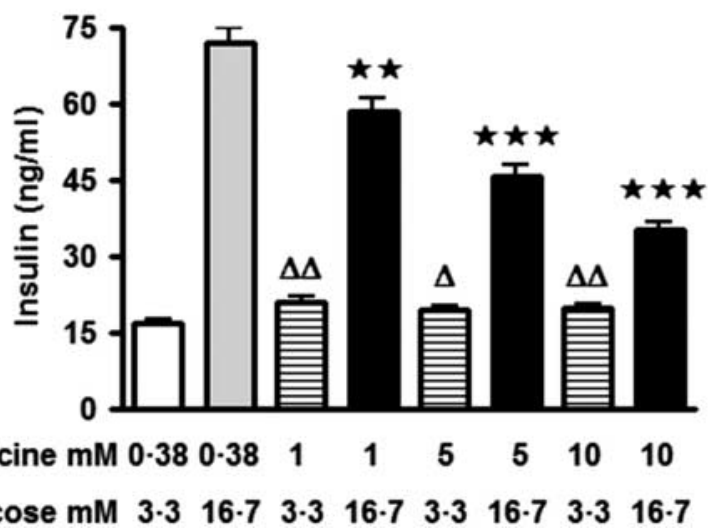

Figure 1 (A) Effects of 72-h incubation with leucine on the response of mouse islets to glucose. The insulin secretion from mouse islets at low $(3 \cdot 3 \mathrm{mM})\left({ }^{\Delta} P<0 \cdot 05,{ }^{\Delta \Delta} P<0 \cdot 01\right)$ and high $(16 \cdot 7 \mathrm{mM})$ glucose concentrations $\left(* P<0 \cdot 05\right.$ and $\left.{ }^{* *} P<0 \cdot 01\right)$ for $1 \mathrm{~h}$ compared with control $(0.38 \mathrm{mM}$ leucine). This part includes three independent experiments. For each experiment, we applied the mean value from 8 to 11 islets for each condition. (B) Effects of 72-h incubation with leucine on the response of INS-1E cells to glucose. The insulin secretion from per 10000 INS-1E cells at low $(3 \cdot 3 \mathrm{mM})\left({ }^{\Delta} P<0 \cdot 05,{ }^{\Delta} P<0 \cdot 01\right)$ and high $(16 \cdot 7 \mathrm{mM})$ glucose concentrations $(* * P<0 \cdot 01, * * * P<0 \cdot 001)$ for 1 h compared with control $(0.38 \mathrm{mM}$ leucine). This part includes three independent experiments. For each experiment, we applied the mean value from six samples for each condition. 
variances. Each treatment condition was compared with controls with Bonferroni's correction. Differences of $P<0 \cdot 05$ were considered to be significant. All statistical analysis was performed with GraphPad Prism Software (San Diego, CA, USA).

\section{Results}

Impact of leucine on insulin secretion from isolated islets and INS-1E cells

Figure $1 \mathrm{~A}$ shows that at $3.3 \mathrm{mM}$ glucose BIS from isolated islets increased after $72-\mathrm{h}$ incubation with 1,5 , or $10 \mathrm{mM}$ leucine. By contrast, glucose $(16 \cdot 7 \mathrm{mM})$-stimulated insulin secretion decreased after 72-h exposure of the islets to 1, 5, or $10 \mathrm{mM}$ leucine (Fig. 1A). Similar results were obtained in INS-1E cells, demonstrating increased BIS and decreased GSIS after 72-h exposure to high leucine concentrations (Fig. 1B). We did not find any change in insulin content after $72-\mathrm{h}$ exposure to 1,5 , and $10 \mathrm{mM}$ leucine compared with control $(0.928 \pm 0.129 \mathrm{ng} / \mu \mathrm{g}$ protein (control), $0.812 \pm 0.136 \mathrm{ng} / \mu \mathrm{g}$ protein (1 mM leucine), $0 \cdot 832 \pm 0 \cdot 107 \mathrm{ng} / \mu \mathrm{g}$ protein $(5 \mathrm{mM}), 0 \cdot 884 \pm 0 \cdot 131 \mathrm{ng} / \mu \mathrm{g}$ protein $(10 \mathrm{mM}))$; after $72 \mathrm{~h}$, no change in insulin output was detected with 1,5 , and $10 \mathrm{mM}$ leucine $(386 \cdot 7 \pm 10 \cdot 5 \mathrm{ng} / \mathrm{ml}$ per 10000 cells (control), 388.8 $\pm 16 \cdot 4 \mathrm{ng} / \mathrm{ml}$ per 10000 cells (1 mM leucine), $365 \cdot 2 \pm 7 \cdot 2 \mathrm{ng} / \mathrm{ml}$ per 10000 cells $(5 \mathrm{mM})$, and $392 \cdot 4 \pm 11 \cdot 0 \mathrm{ng} / \mathrm{ml}$ per 10000 cells $(10 \mathrm{mM})$ ).

Effects of 72-h exposure to leucine on gene expressions in INS-1E cells

The impact of 72-h incubation with $5 \mathrm{mM}$ leucine on gene expression was studied in INS-1E cells for a number of $\beta$-cell genes (Fig. 2A, B, C, D, E, F, G, H, I, J, K, and L). Leucine upregulated $P d x 1$ expression (Fig. 2A), did not change MafA expression (Fig. 2B), downregulated Ins 1 expression (Fig. 2C), and upregulated Ins2 expression (Fig. 2D). As shown in Fig. 2E and F, leucine increased Acaca and Fasn expressions in INS-1E cells.

As depicted in Fig. 2G, leucine significantly increased Srebf 2 mRNA expression. Figure 2H, I and J demonstrate changes in the expression of a series of genes encoding for enzymes involved in $\mathrm{CH}$ biosynthesis in INS-1E cells exposed to leucine. Hmgcr, Mvd, and Sqle were upregulated. Leucine also increased Ldlr mRNA level in INS-1E cells (Fig. 2K). By contrast, leucine pronouncedly reduced Cox $6 a 2$ mRNA level in INS-1E cells (Fig. 2L).
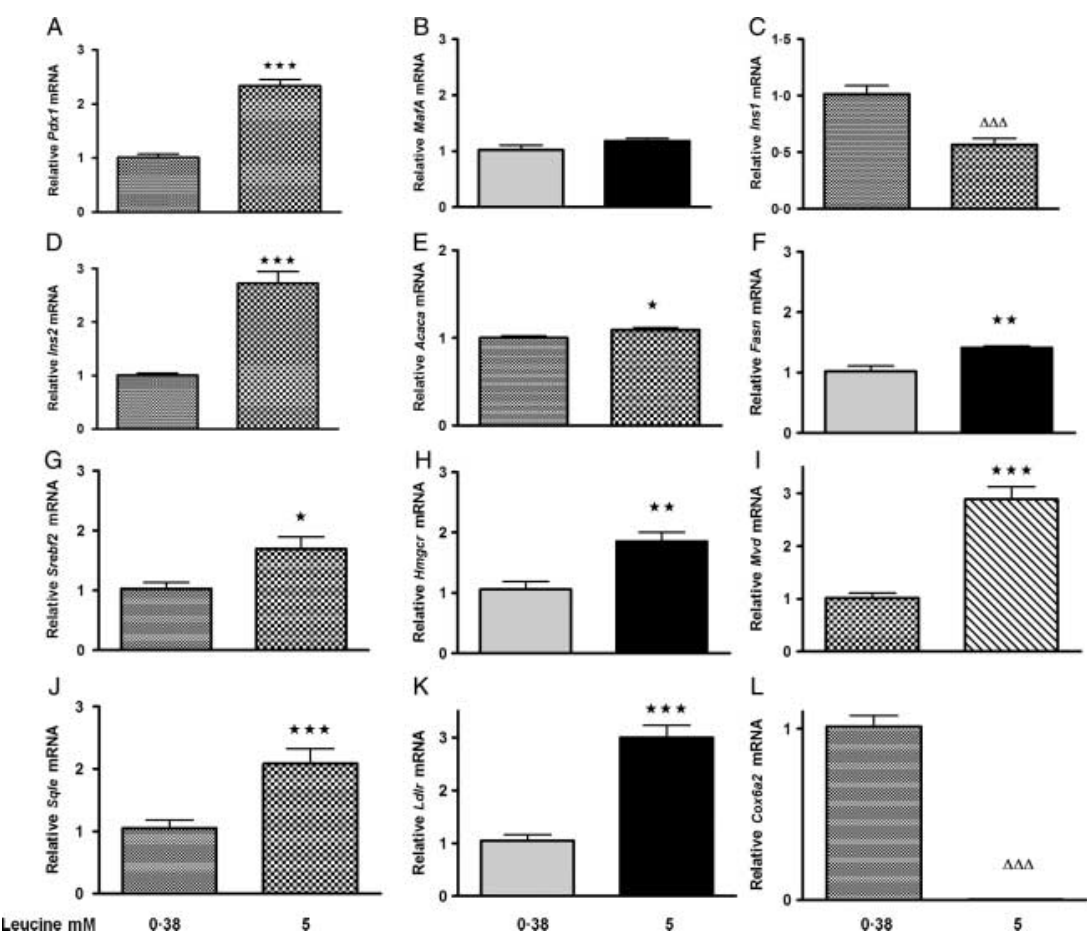

Figure 2 Changes in gene expressions in INS-1E cells induced by $5 \mathrm{mM}$ leucine. The following genes were investigated: Pdx1 (A), MafA (B), Ins1 (C), Ins2 (D), Acaca (E), Fasn (F), Srebf2 (G), Hmgcr (H), Mvd (I), Sqle (J), Ldlr (K), and Cox6a2 (L). ${ }^{*} P<0 \cdot 05$, ${ }^{* *} P<0 \cdot 01,{ }^{* * *} P<0 \cdot 001$ vs control, ${ }^{\Delta \Delta \Delta} P<0 \cdot 001$ vs control. RNA extraction includes three experiments applying different passage number cells. RT-PCR was performed in six repeats. 
Influence of leucine on TG and CH content in INS-1E cells

As seen in Fig. 3A, 72-h incubation with leucine (1, 5, or $10 \mathrm{mM}$ ) reduced the TG content of INS-1E cells significantly. Figure $3 \mathrm{~B}$ demonstrates that the $\mathrm{CH}$ content in INS-1E cells was increased after 72 -h culture with 1,5 , or $10 \mathrm{mM}$ leucine respectively.

Effect of leucine on gene expressions associated with apoptosis in INS-1E cells

Leucine $(5 \mathrm{mM})$ did not affect the mRNA levels of Casp3 (Fig. 4A) and Dapk3 (Fig. 4B) in INS-1E cells, whereas the pro-apoptotic protein Bmf (Fig. 4C) mRNA was downregulated.

Impact of leucine on the viability of INS-1E cells and

${ }^{3} \mathrm{H}$-thymidine incorporation in INS-1E cells culture

While the percentage of dead INS-1E cells was unchanged by 1 and $5 \mathrm{mM}$ leucine, $10 \mathrm{mM}$ leucine augmented the number of dead INS-1E cells (Fig. 5A). Leucine (1, 5, and $10 \mathrm{mM}$ )
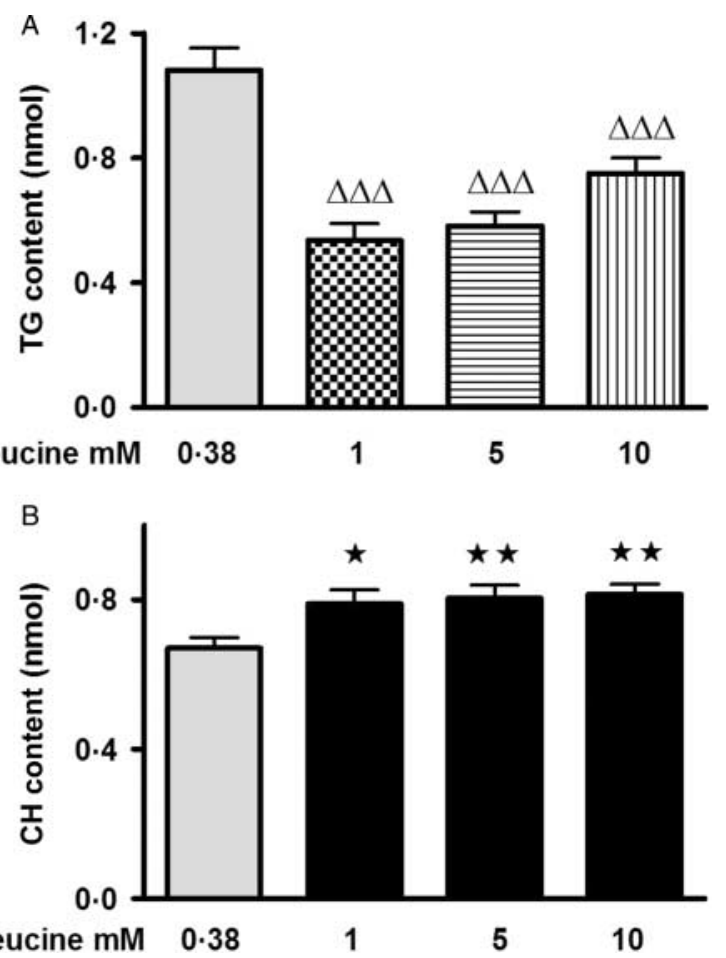

$\begin{array}{ccccc}\text { Leucine } \mathrm{mM} & \mathbf{0 . 3 8} & \mathbf{1} & \mathbf{5} & 10 \\ \text { Figure } 3 & \text { (A) Effect of leucine } & \text { on } & \text { TG content of } & \text { INS-1E cells. }\end{array}$ Changes in TG content per 10000 INS-1E cells after 72-h incubation with leucine $(1-10 \mathrm{mM}) .{ }^{\Delta \Delta \Delta} P<0 \cdot 001 \mathrm{vs}$ control. This part includes three independent experiments. For each experiment, we applied the mean value from six samples for each condition. (B) Effect of leucine on CH content of INS-1E cells. Changes in $\mathrm{CH}$ content per 10000 INS-1 E cells after 72-h incubation with $1-10 \mathrm{mM}$ leucine, ${ }^{*} P<0 \cdot 05, * * P<0 \cdot 01$ vs control. This part includes three independent experiments. For each experiment, we applied the mean value from six samples for each condition.
A

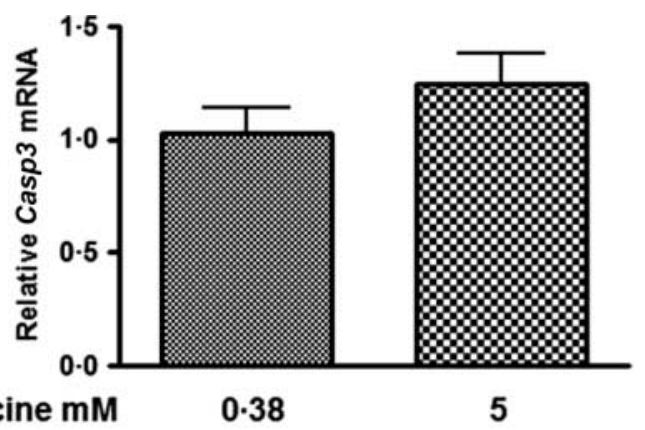

Leucine $\mathrm{mM}$

0.38

5
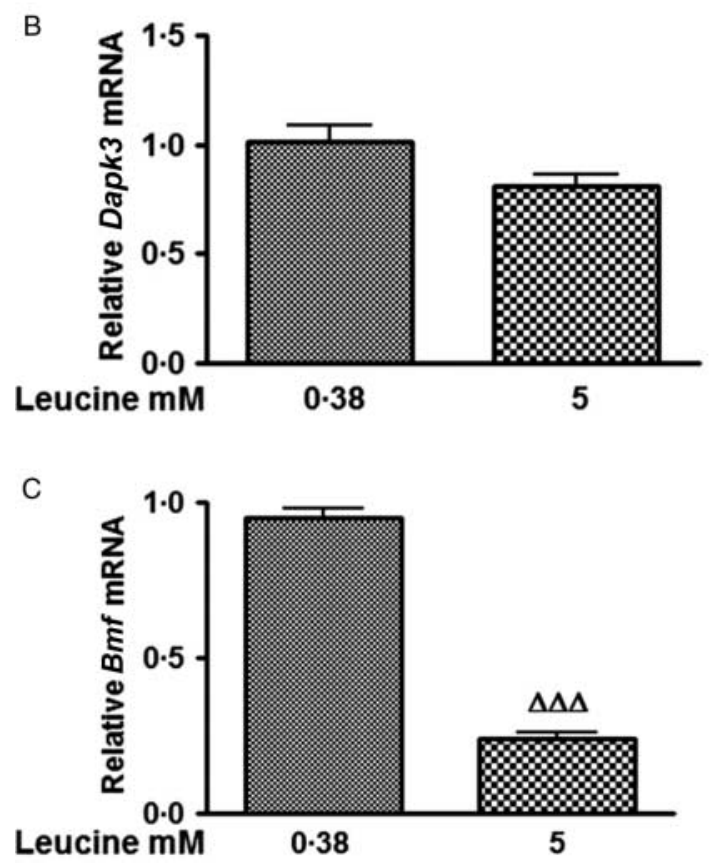

Figure 4 Impact of leucine on the expressions of genes associated with apoptosis. Alterations of mRNA expression in genes associated with apoptosis in INS-1E cells induced by $72 \mathrm{~h}$ exposure to $5 \mathrm{mM}$ leucine. Casp3 (A), Dapk3 (B), Bmf (C), ${ }^{\Delta \Delta}{ }_{P<0 \cdot 001} \mathrm{vs}$ control. RNA extraction includes three independent experiments. RT-PCR was performed in six repeats.

decreased ${ }^{3} \mathrm{H}$-thymidine incorporation in INS-1E cells, indicating a leucine-induced suppression of INS-1E cell proliferation (Fig. 5B).

Proteomics studies: alteration in proteins in INS-1E cells induced by leucine

Results from proteomic studies are presented in Table 1. Leucine $(5 \mathrm{mM})$ increased the autophagy-related enzyme, cathepsin D. Leucine decreased serine/threonine-protein phosphatase PP1, which is related to phosphorylation/ dephosphorylation states of proteins. Leucine decreased GTP-binding nuclear protein and increased dihydropyrimidinase-related protein 2 (DRP2), which are related to ISG 

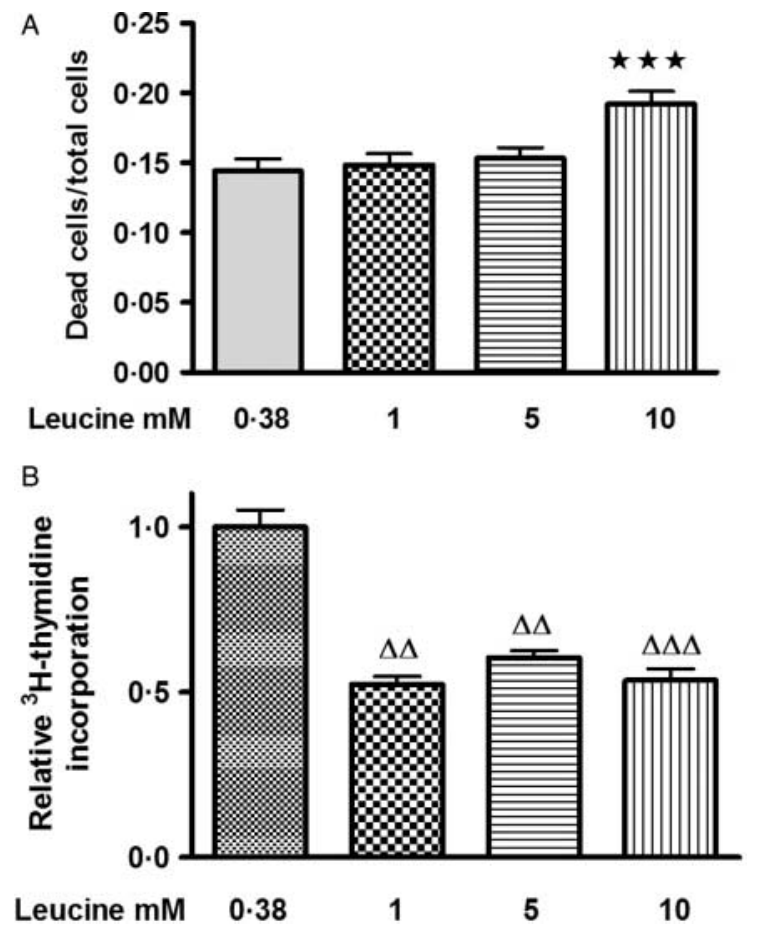

Figure 5 (A) Impact of leucine on the viability of INS-1E cells. Impact of 72-h incubation with leucine (1-10 mM) on the viability of INS-1E cells, ${ }^{* * *} P<0 \cdot 001$ vs control. This part includes three independent experiments. For each experiment, we applied the mean value from ten samples for each condition. (B) Effect of leucine on the incorporation of ${ }^{3} \mathrm{H}$-thymidine into INS-1E cells. Effect of 72-h incubation with leucine $(1-10 \mathrm{mM})$ on ${ }^{3} \mathrm{H}$-thymidine incorporation in INS-1E cells, ${ }^{\Delta \Delta} P<0 \cdot 01,{ }^{\Delta \Delta \Delta} P<0 \cdot 001$ vs control. This part includes three independent experiments. For each experiment, we applied the mean value from ten samples for each condition.

transport/trafficking. Proteasome subunit $\alpha$ type 6 was identified in two spots, one was upregulated, while the other was downregulated; the two spots are probably active and inactive forms of proteasome subunit $\alpha$ type 6 .

\section{Discussion}

In this study, we demonstrated that long-term exposure to leucine caused $\beta$-cell dysfunction with increased BIS and decreased GSIS in both mouse islets and INS-1E cells respectively. The functional derangement of $\beta$ cells took place concomitantly with alterations in a large number of $\beta$-cell gene expressions. For example, Ins 1 gene expression was downregulated by chronic exposure to high leucine levels (Fig. 2C), being in line with the observation that GSIS was inhibited and that Ins1 accounts for $60-90 \%$ of total insulin immunoreactivity in $\beta$-cell lines (Linde et al. 1993). The expressions of the two insulin genes have been proposed to be independently regulated as well as coordinately regulated in both rats and mice (Linde et al. 1993). The differential effect of leucine on expressions of Ins 1 and Ins 2 mRNA (Fig. 2D) appears puzzling. There was no change in total insulin content or output in INS-1E cells. $P d x 1$ and MafA are potent stimulators of the transcription of insulin genes (Docherty et al. 2005), and the increased $P d x 1$ mRNA expression found in this study (Fig. 2A) is very interesting; it is in accordance with increased mRNA expression of $P d x 1$ in isolated islets from T2D patients, despite less insulin release than control islets in response to glucose (Del Guerra et al. 2005); furthermore, it has previously been shown that glutamine upregulates $P d x 1$ expression in BRIN-BD11 cells (Corless et al. 2006).

In a global gene expression profiling study (Liu et al. 2011), the largest cluster of genes in INS-1E cells induced by exposure to excess leucine is those regulating $\mathrm{CH}$ metabolism. AMP-activated protein kinase $(A M P K)$ was downregulated (Liu et al. 2011), Srebf 2 mRNA expression was enhanced (Figs 2G and 6), and as many as ten enzymes in the $\mathrm{CH}$ biosynthetic pathway were upregulated (Liu et al. 2011). In line with the change of $A M P K$ in INS-1E cells after prolonged exposure to leucine, islets from T2D patients demonstrated that the percentage of activated AMPK protein was significantly lower than control islets (Del Guerra et al. 2005). The principal targets for phosphorylation by AMPK are Hmgcr and Acaca (Towler \& Hardie 2007). Interestingly, Srebf2 gene is tightly associated with the regulation of a number of genes encoding for enzymes involved in the $\mathrm{CH}$ biosynthetic pathway (Ishikawa et al. 2008). Our RT-PCR results showed that leucine upregulated expressions of $\mathrm{CH}$ biosynthetic enzymes, e.g. acetyl-CoA acetyltransferase 2, 3-hydroxy-3-methylglutaryl-CoA synthase 1 (Liu et al. 2011), Hmgcr, Mvd, Sqle (Fig. 2H, I, and J), and Ldlr (Fig. 2K). In line with this, we found that the $\mathrm{CH}$ content was significantly increased in INS-1E cells chronically exposed to elevated leucine levels (Fig. 3B). The series of events

Table 1 INS-1E cellular proteins identified by MS and significantly affected by leucine. Fold change (FC) in mean relative spot volumes was calculated relative to the control, FC $>1$ indicates upregulation, $\mathrm{FC}<1$ indicates downregulation

\begin{tabular}{|c|c|c|c|c|}
\hline Protein name & $\begin{array}{l}\text { Swiss Prot } \\
\text { Acc. no. }^{\mathrm{a}}\end{array}$ & $\begin{array}{l}\text { Mouse } \\
\text { score }^{b}\end{array}$ & $\begin{array}{l}\boldsymbol{t} \text {-test } \\
(P)\end{array}$ & $\begin{array}{l}\text { Fold } \\
\text { change }\end{array}$ \\
\hline $\begin{array}{l}\text { Pyruvate dehydrogenase } \\
\text { E1 component } \\
\text { subunit } \beta\end{array}$ & P49432 & $73 *$ & $0 \cdot 02$ & $1 \cdot 3$ \\
\hline Cathepsin D & P24268 & 59 & $0 \cdot 002$ & $1 \cdot 5$ \\
\hline $\begin{array}{l}\text { Serine/threonine-protein } \\
\text { phosphatase PP1 }\end{array}$ & P62138 & $115^{*}$ & $0 \cdot 04$ & 0.9 \\
\hline $\begin{array}{l}\text { Dihydro pyridiminase- } \\
\text { related protein } 2\end{array}$ & P47942 & $70^{*}$ & $0 \cdot 03$ & $1 \cdot 4$ \\
\hline $\begin{array}{l}\text { Proteasome subunit } \alpha \\
\text { type } 6\end{array}$ & P60901 & $89 *$ & $0 \cdot 03$ & $0 \cdot 8$ \\
\hline $\begin{array}{l}\text { Proteasome subunit } \alpha \\
\text { type } 6\end{array}$ & P60901 & $82^{*}$ & $0 \cdot 0003$ & $2 \cdot 1$ \\
\hline $\begin{array}{l}\text { GTP-binding nuclear } \\
\text { protein }\end{array}$ & P62828 & $65^{*}$ & $0 \cdot 05$ & $0 \cdot 5$ \\
\hline
\end{tabular}

aprimary accession key in the SWISS-PROT database.

${ }^{\mathrm{b}} \mathrm{S}$ core of the Mascot search. Significant scores $(P<0 \cdot 05)$ are marked by * 


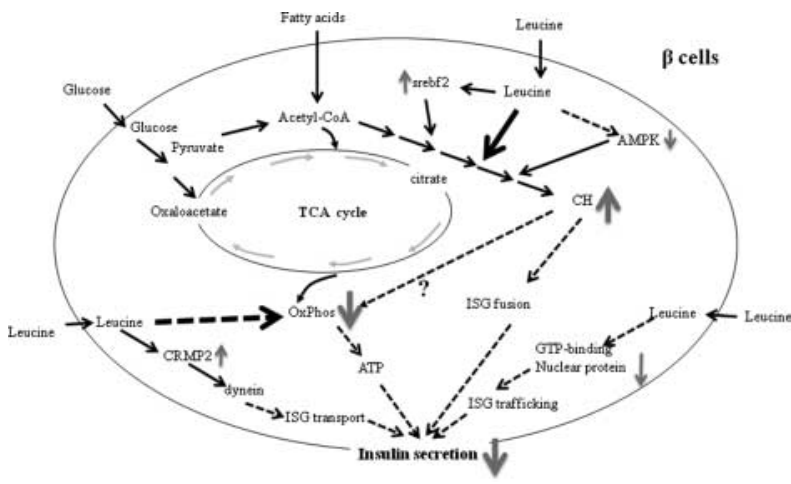

Figure 6 Scheme depicting major pathways relating to the possible effects of leucine on pancreatic $\beta$ cells. AMPK, AMP-activated protein kinase; $\mathrm{CH}$, cholesterol; CRMP-2, collapsin response mediator protein 2; ISGs, insulin secretory granules; OxPhos, oxidative phosphorylation; Srebf2, sterol-regulatory element binding factor 2; TCA, tricarboxylic acid. Dashed line arrow indicates negative effect, solid line arrow indicates positive effect.

described here is coherent with several data obtained in vitro and in vivo in animal models and have recently been put into perspective (Peyot et al. 2010, Vergeer et al. 2010, Kruit et al. 2012). Combined deletion of ATP-binding cassette transporter G subfamily 1 (ABCG1) and the ATP-binding cassette transporter subfamily A member 1 (ABCA1) resulted in increased islet $\mathrm{CH}$ levels compared with control, $\beta$-cellspecific ABCA1 deficiency, and globally deficient ABCG1; notably, islets lacking both ABCA1 and ABCG1 had an even greater reduction in GSIS compared with islets from mice lacking either ABCA1 or ABCG1 (Kruit et al. 2012). Likewise, high-fat induced obese mice were divided into low responders (LDR) and high responders (HDR) according to their body weight (Peyot et al. 2010). There was a 90\% and $60 \%$ increase in free $\mathrm{CH}$ in islets from $\mathrm{HDR}$ and LDR respectively; LDR mice islets displayed impaired GSIS, whereas GSIS of HDR mice islets was almost blunted. Moreover, in ABCA1 heterozygotes, the first-phase insulin response is significantly impaired (Vergeer et al. 2010).

Consistent with the downregulation of $A M P K$, long-term exposure to extra leucine results in upregulation of Acaca and Fasn mRNA expressions in INS-1E cells (Fig. 2E and F). Corless et al. (2006) previously also found increased Acaca expression to glutamine. These suggest that leucine may inhibit FA $\beta$ oxidation and favor $\mathrm{CH}$ and FA synthesis. To our surprise, increased levels of leucine resulted in TG reduction in INS-1E cells (Fig. 3A). One explanation might be that leucine strongly induced an increase in $\mathrm{CH}$ biosynthesis and is associated with higher consumption of substrate. This may result in a shortage of substrate for TG synthesis and a reduction in TG content.

INS-1E cells demonstrated a robust suppression of Cox6a2 gene expression assessed by both microarray (Liu et al. 2011) and RT-PCR (Fig. 2L) after prolonged exposure to excess leucine (Fig. 6). Cox represents the terminal and rate-limiting enzyme complex of the OxPhos pathway, which is responsible for ATP production in mitochondria. The critical regulatory role of ATP production by $\mathrm{OxPhos}$ is underscored by the observation that the Cox activity of islets from the transgenic MKR mouse (a dominant-negative IGF1 receptor mutation specifically in skeletal muscle) was significantly reduced (Lu et al. 2010). As a result, the ATP/ADP ratio was blunted in response to high glucose, and this was followed by a blocking of GSIS, indicating a reduced mitochondrial oxidative capacity ( $\mathrm{Lu}$ et al. 2010). Accordingly, advanced glycation end products cause impaired GSIS from mice islets and INS-1 cells by inhibiting Cox activity and ATP synthesis (Zhao et al. 2009). This is in line with observations in human diabetes. The expression of a co-regulated subset of OxPhos in individuals with IGT was also downregulated, indicating that downregualtion of a co-regulated subset of OxPhos precedes onset of T2D (Mootha et al. 2003). Taken together, this highlights Cox as an important mechanism by which leucine impairs GSIS in INS-1E cells. Previously, clonal BRIN-BD11 $\beta$ cells exposed to alanine for $24 \mathrm{~h}$ exhibited impaired alanine-induced insulin secretion (Cunningham et al. 2005). Intriguingly, in CH-enriched $\beta$ cells, the glucosemediated increase in cellular ATP content was dramatically reduced, and this was related to a decrease in glucose uptake via glucose transporter 2 and an impairment of mitochondrial metabolism (Lee et al. 2011). The relationship between leucine-induced $\mathrm{CH}$ accumulation and leucine-induced Cox downregulation should be further investigated (Fig. 6). Cox activity is also regulated by phosphorylation and dephosphorylation. As many as at least ten of the 13 subunits of Cox could be phosphorylated at serine and/or threonine residues (Thompson 2002). As seen from our proteomics results, we found that serine/threonine-protein phosphatase 1 decreased in leucine-treated INS-1E cells (Table 1). Its significance should be further explored deeply.

DRP2 also known as collapsin response mediator protein 2 (CRMP2) plays a role in the maintenance of intracellular $\mathrm{Ca}^{2+}$ homeostasis by direct binding to cytoplasmic loops of N-type $\mathrm{Ca}^{2+}$ channels (Wang et al. 2010). Moreover, CRMP2 directly bound cytoplasmic dynein and prevented dynein-driven microtubule transport in COS-7 cells (Arimura et al. 2009). Leucine significantly increased CRMP2 content in INS-1E cells (Table 1), indicating a potentially detrimental effect on insulin secretion (Fig. 6), which needs to be corroborated in $\beta$ cells. Furthermore, by the application of proteomics, we found that leucine reduced the expression of GTP-binding nuclear protein Ran (Table 1) in INS-1E cells, which has been reported to be involved in the regulation of microtubule assembly (Dikovskaya et al. 2010). In accordance with our findings, elevated islet $\mathrm{CH}$ accumulation due to a lack of $\beta$-cell ABCA1 directly impairs depolarizationinduced exocytotic fusion of ISGs (Kruit et al. 2011; Fig. 6). Leucine-induced cellular $\mathrm{CH}$ accumulation, CRMP2 upregulation, and GTP-binding nuclear protein downregulation are new findings and deserve further evaluation. These findings may have relevance for ISG exocytotic fusion, ISG transport, and trafficking in pancreatic $\beta$ cells (Fig. 6). 
Another protein identified as being differentially regulated by leucine was proteasome subunit $\alpha$ type 6 (Table 1 ). Interestingly, insulin receptor substrate 1 (IRS1) is selectively regulated by a proteasome degradation pathway activated during prolonged insulin exposure. This is accomplished through regulation of the amount of IRS1, an important receptor-related component in the insulin-signaling cascade (Zhande et al. 2002). Furthermore, leucine diminished insulin receptor expression (Liu et al. 2011) and upregulated ribosomal protein S6 kinase polypeptide $1 \mathrm{mRNA}$ level in INS-1E cells (Liu et al. 2011), the latter inhibited serine phosphorylation of IRS1 to impair insulin action (Tremblay et al. 2005). Consequently, leucine appears to induce IR through multiple mechanisms (Tremblay et al. 2005, Balage et al. 2011).

Currently, there is doubt that apoptosis is a major $\beta$-cell death mechanism in T2D. We found no indication that leucine affects INS-1E cell death at the concentrations of 1 and $5 \mathrm{mM}$ (Fig. 5A), results that are in agreement with Zhang et al. (2009). This was further supported by the gene expressions of key mediators in apoptosis using RT-PCR. Thus, $5 \mathrm{mM}$ leucine did not change Casp3 (Fig. 4A) and Dapk3 (Fig. 4B) expressions in INS-1E cells. Moreover, leucine significantly downregulated Bmf expression in INS-1E cells (Fig. 4C), suggesting an anti-apoptosis effect of leucine. The amount of $\beta$-cell mass, at any given moment, is represented by the sum of replication, size, and neogenesis minus the rate of apoptosis. The ${ }^{3} \mathrm{H}$-thymidine incorporation experiment showed that INS-1E cell proliferation was obviously reduced by exposure to elevated leucine levels for $72 \mathrm{~h}$ (Fig. 5B). This suggests that elevated leucine may cause reduced $\beta$-cell mass by decreasing $\beta$-cell mitotic division and proliferation.

In conclusion, chronic exposure to elevated levels of leucine induces $\beta$-cell dysfunction, with increased BIS and decreased GSIS in both isolated mouse islets and clonal $\beta$ cells. Accordingly, long-term exposure of INS-1E cells to excess leucine resulted in abnormal $\mathrm{CH}$ metabolism, impaired OxPhos, and insulin signal transduction. Overall, these observations indicate that exposure to leucine may have detrimental effects on both $\beta$-cell function and insulin sensitivity.

\section{Declaration of interest}

The authors declare that there is no conflict of interest that could be perceived as prejudicing the impartiality of the research reported.

\section{Funding}

This work is carried out as a part of the research program of the Danish Obesity Research Centre (DanORC, see www.danorc.dk). The study was supported by The China Scholarship Council, The Daloon foundation, The TOYOTA-Foundation, Denmark, Institute of Experimental Clinical Research, Aarhus University, and the Nordic Centre of Excellence Programme (Systems biology in controlled dietary interventions and cohort studies-SYSDIET, P no. 070014).

\section{Author contribution statement}

Z L, P B J, S G, and $\mathrm{K} \mathrm{H}$ designed this project, Z L completed experiments described in this manuscript. L B L completed proteomics experiment. P B J and $\mathrm{S} G$ provided experimental advice. $\mathrm{Z} \mathrm{L}$ wrote the manuscript; $\mathrm{K} \mathrm{H}, \mathrm{P} \mathrm{B} \mathrm{J}$, S G, and L B L helped with manuscript revision.

\section{Acknowledgements}

The authors thank Dorthe Rasmussen, Lene Trudsø, Kirsten Eriksen, Hanne Søndergaard Møller, and Tove Skrumsager Hansen for skilled technical assistance and Michael Væth (Department of Biostatistics, Aarhus University) for statistical advice.

\section{References}

Anello M, Ucciardello V, Piro S, Patané G, Frittitta L, Calabrese V, Giuffrida Stella AM, Vigneri R, Purrello F \& Rabuazzo AM 2001 Chronic exposure to high leucine impairs glucose-induced insulin release by lowering the ATP-to-ADP ratio. American Journal of Physiology Endocrinology and Metabolism 281 E1082-E1087.

Arimura N, Hattori A, Kimura T, Nakamuta S, Funahashi Y, Hirotsune S, Furuta K, Urano T, Toyoshima YY \& Kaibuchi K 2009 CRMP-2 directly binds to cytoplasmic dynein and interferes with its activity. Journal of Neurochemistry 111 380-390. (doi:10.1111/j.1471-4159.2009.06317.x)

Balage M, Dupont J, Mothe-Satney I, Tesseraud S, Mosoni L \& Dardevet D 2011 Leucine supplementation in rats induced a delay in muscle IR/PI3K signaling pathway associated with overall impaired glucose tolerance. Journal of Nutritional Biochemistry 22 219-226. (doi:10.1016/j.jnutbio.2010. 02.001)

Corless M, Kiely A, McClenaghan NH, Flatt PR \& Newsholme P 2006 Glutamine regulates expression of key transcription factor, signal transduction, metabolic gene, and protein expression in a clonal pancreatic $\beta$-cell line. Journal of Endocrinology 190 719-727. (doi:10.1677/joe.1.06892)

Cunningham GA, McClenaghan NH, Flatt PR \& Newsholme P 2005 $\mathrm{L}$-alanine induces changes in metabolic and signal transduction gene expression in a clonal rat pancreatic $\beta$-cell line and protects from proinflammatory cytokine-induced apoptosis. Clinical Science 109 447-455. (doi:10.1042/CS20050149)

Del Guerra S, Lupi R, Marselli L, Masini M, Bugliani M, Sbrana S, Torri S, Pollera M, Boggi U, Mosca F et al. 2005 Functional and molecular defects of pancreatic islets in human type 2 diabetes. Diabetes 4 727-735. (doi:10.2337/diabetes.54.3.727)

Dikovskaya D, Li Z, Newton IP, Davidson I, Hutchins JR, Kalab P, Clarke PR \& Näthke IS 2010 Microtubule assembly by the Apc protein is regulated by importin- $\beta$-RanGTP. Journal of Cell Science 123 736-746. (doi:10.1242/jcs. 060806)

Docherty HM, Hay CW, Ferguson LA, Barrow J, Durward E \& Docherty K 2005 Relative contribution of PDX-1, MafA and E47/ $\beta 2$ to the regulation of the human insulin promoter. Biochemical Journal 389 813-820. (doi:10.1042/BJ20041891)

El-Assaad W, Joly E, Barbeau A, Sladek R, Buteau J, Maestre I, Pepin E, Zhao S, Iglesias J, Roche E et al. 2010 Glucolipotoxicity alters lipid partitioning and causes mitochondrial dysfunction, cholesterol, and ceramide deposition and reactive oxygen species production in INS832/13 $\beta$-cells. Endocrinology 151 3061-3073. (doi:10.1210/en.2009-1238)

Ferrannini E, Gastaldelli A, Miyazaki Y, Matsuda M, Pettiti M, Natali A, Mari A \& DeFronzo RA 2003 Predominant role of reduced $\beta$-cell sensitivity to glucose over insulin resistance in impaired glucose tolerance. Diabetologia 46 1211-1219. (doi:10.1007/s00125-003-1169-6)

Ishikawa M, Iwasaki Y, Yatoh S, Kato T, Kumadaki S, Inoue N, Yamamoto T, Matsuzaka T, Nakagawa Y, Yahagi N et al. 2008 Cholesterol accumulation 
and diabetes in pancreatic $\beta$-cell-specific SREBP-2 transgenic mice: a new model for lipotoxicity. Journal of Lipid Research 49 2524-2534. (doi:10.1194/jlr.M800238-JLR200)

Kalogeropoulou D, Lafave L, Schweim K, Gannon MC \& Nuttall FQ 2008 Leucine, when ingested with glucose, synergistically stimulates insulin secretion and lowers blood glucose. Metabolism 57 1747-1752. (doi:10.1016/j.metabol.2008.09.001)

Kang DH, Gho YS, Suh MK \& Kang CH 2002 Highly sensitive and fast protein detection with coomassie brilliant blue in sodium dodecyl sulfatepolyacrylamide gel electrophoresis. Bulletin of the Korean Chemical Society 23 1511-1512. (doi:10.5012/bkcs.2002.23.11.1511)

Kruit JK, Wijesekara N, Fox JEM, Dai XQ, Brunham LR, Searle GJ, Morgan GP, Costin AJ, Tang R, Bhattacharjee A et al. 2011 Islet cholesterol accumulation due to loss of ABCA1 leads to impaired exocytosis of insulin granules. Diabetes 60 3186-3196. (doi:10.2337/db11-0081)

Kruit JK, Wijesekara N, Westwell-Roper C, Vanmierlo T, de Haan W, Bhattacharjee A, Tang R, Wellington CL, LütJohann D, Johnson JD et al. 2012 Loss of both ABCA1 and ABCG1 results in increased disturbances in islet sterol homeostasis, inflammation, and impaired $\beta$-cell function. Diabetes 61 659-664. (doi:10.2337/db11-1341)

Lacy PE \& Kostianovsky M 1967 Method for the isolation of intact islets of Langerhans from the rat pancreas. Diabetes 16 35-39.

Larsen LB, Wedholm-Pallas A, Lindmark-Månsson H \& Andrén A 2010 Different proteomic profiles of sweet whey and rennet casein obtained after preparation from raw versus heat treated skimmed milk. Dairy Science \& Technology 90 641-656. (doi:10.1051/dst/2010024)

Lee AK, Yeung-Yam-Wah V, Tse FW \& Tse A 2011 Cholesterol elevation impairs glucose-stimulated $\mathrm{Ca}(2+)$ signaling in mouse pancreatic $\beta$-cells. Endocrinology 152 3351-3361. (doi:10.1210/en.2011-0124)

Linde S, Welinder BS \& Nielsen JH 1993 Analysis of proinsulin and its conversion products by reversed- phase high-performance liquid chromatography. Journal of Chromatography 614 185-204. (doi:10.1016/03784347(93)80309-R)

Liu Z, Jeppesen PB, Gregersen S, Chen X \& Hermansen K 2008 Dose- and glucose-dependent effects of amino acids on insulin secretion from isolated mouse islets and clonal INS-1E $\beta$-cells. Review of Diabetic Studies 5 232-244. (doi:10.1900/RDS.2008.5.232)

Liu Z, Luo Y, Jerpersen BP, Gregersen S \& Hermansen K 2011 Amino acid induced gene expression profiling in clonal $\beta$ cell line INS-1E cells. Diabetes/Metabolism Research and Reviews 27 120-176. (doi:10.1002/dmrr. 1153)

Lu H, Koshkin V, Allister EM, Gyulkhandanyan AV \& Wheeler MB 2010 Molecular and metabolic evidence for mitochondrial defects associated with $\beta$-cell dysfunction in a mouse model of type 2 diabetes. Diabetes $\mathbf{5 9}$ 448-459. (doi:10.2337/db09-0129)

MacDonald MJ, Hasan NM \& Longacre MJ 2008 Studies with leucine, $\beta$-hydroxybutyrate and ATP citrate lyase-deficient $\beta$ cells support the acetoacetate pathway of insulin secretion. Biochimica et Biophysica Acta $\mathbf{1 7 8 0}$ 966-972. (doi:10.1016/j.bbagen.2008.03.017)

Mootha VK, Lindgren CM, Eriksson KF, Subramanian A, Sihag S, Lehar J, Puigserver P, Carlsson E, Ridderstråle M, Laurila E et al. 2003 PGC-1 $\alpha$ responsive genes involved in oxidative phosphorylation are coordinately downregulated in human diabetes. Nature Genetics 34 267-273. (doi:10.1038/ng1180)

Newgard CB, An J, Bain JR, Muehlbauer MJ, Stevens RD, Lien LF, Haqq AM, Shah SH, Arlotto M, Slentz CA et al. 2009 A branched-chain amino acid-related metabolic signature that differentiates obese and lean humans and contributes to insulin resistance. Cell Metabolism 9 311-326. (doi:10.1016/j.cmet.2009.02.002)

Newsholme P, Brennan L \& Bender K 2006 Amino acid metabolism, $\beta$-cell function, and diabetes. Diabetes 55 (Suppl 2) s39-s47. (doi:10.2337/db06S006)

Peyot ML, Pepin E, Lamontagne J, Latour MG, Zarrouki B, Lussier R, Pineda M, Jetton TL, Madiraju SR, Joly E et al. $2010 \beta$ Cell failure in diet-induced obese mice stratified according to body weight gain: secretory dysfunction and altered islet lipid metabolism without steatosis or reduced $\beta$ cell mass. Diabetes 59 2178-2187. (doi:10.2337/db09-1452)

Pfaffl MW 2001 A new mathematical model for relative quantification in realtime RT-PCR. Nucleic Acids Research 29 e45. (doi:10.1093/nar/29.9.e45)

Sakai K, Hayashi C, Yamaji H \& Fukuda H 2001 Use of nonionic surfactants for effective supply of phosphatidic acid in serum-free culture of Chinese hamster ovary cells. Journal of Bioscience and Bioengineering 92 256-261. (doi:10.1016/S1389-1723(01)80259-0)

Thompson M 2002 Evidence of undiscovered cell regulatory mechanisms: phosphoproteins and protein kinases in mitochondria. Cellular and Molecular Life Sciences 59 213-219. (doi:10.1007/s00018-002-8417-7)

Towler MC \& Hardie DG 2007 AMP-activated protein kinase in metabolic control and insulin signaling. Circulation Research 100 328-341. (doi:10.1161/01.RES.0000256090.42690.05)

Tremblay F, Krebs M, Dombrowski L, Brehm A, Bernroider E, Roth E, Nowotny P, Waldhäusl W, Marette A \& Roden M 2005 Overactivation of S6 kinase 1 as a cause of human insulin resistance during increased amino acid availability. Diabetes 54 2674-2684. (doi:10.2337/diabetes.54.9.2674)

Vergeer M, Brunham LR, Koetsveld J, Kruit JK, Verchere CB, Kastelein JJ, Hayden MR \& Stroes ES 2010 Carriers of loss-of-function mutations in ABCA1 display pancreatic $\beta$-cell dysfunction. Diabetes Care 33 869-874. (doi:10.2337/dc09-1562)

Wang Y, Brittain JM, Wilson SM \& Khanna R 2010 Emerging roles of collapsin response mediator proteins (CRMPs) as regulators of voltagegated calcium channels and synaptic transmission. Communicative $\mathcal{E}$ Integrative Biology 3 172-175. (doi:10.4161/cib.3.2.10620)

Xiao J, Gregersen S, Kruhøffer M, Pedersen SB, Ørntoft TF \& Hermansen K 2001 The effect of chronic exposure to fatty acids on gene expression in clonal insulin-producing cells: studies using high density oligonucleotide microarray. Endocrinology 142 4777-4784. (doi:10.1210/en.142.11.4777)

Yang J, Wong RK, Park M, Wu J, Cook JR, York DA, Deng S, Markmann J, Naji A, Wolf BA et al. 2006 Leucine regulation of glucokinase and ATP synthase sensitizes glucose-induced insulin secretion in pancreatic $\beta$-cells. Diabetes 55 193-201. (doi:10.2337/diabetes.55.01.06.db05-0938)

Young JF, Larsen LB, Malmendal A, Nielsen NC, Straadt IK, Oksbjerg N \& Bertram HC 2010 Creatine- induced activation of antioxidative defence in myotube cultures revealed by explorative NMR- based metabonomics and proteomics. Journal of the International Society of Sports Nutrition 79. (doi:10.1186/1550-2783-7-9)

Zhande R, Mitchell JJ, Wu J \& Sun XJ 2002 Molecular mechanism of insulininduced degradation of insulin receptor substrate 1. Molecular and Cellular Biology 22 1016-1026. (doi:10.1128/MCB.22.4.1016-1026.2002)

Zhang Y, Guo K, LeBlanc RE, Loh D, Schwartz GJ \& Yu YH 2007 Increasing dietary leucine intake reduces diet-induced obesity and improves glucose and cholesterol metabolism in mice via multi-mechanisms. Diabetes $\mathbf{5 6}$ 1647-1654. (doi:10.2337/db07-0123)

Zhang X, Sun N, Wang L, Guo H, Guan Q, Cui B, Tian L, Gao L \& Zhao J 2009 AMP-activated protein kinase and pancreatic/duodenal homeobox-1 involved in insulin secretion under high leucine exposure in rat insulinoma $\beta$-cells. Journal of Cellular and Molecular Medicine 13 758-770. (doi:10.1111/ j.1582-4934.2009.00656.x)

Zhao Z, Zhao C, Zhang XH, Zheng F, Cai W, Vlassara H \& Ma ZA 2009 Advanced glycation end products inhibit glucose-stimulated insulin secretion through nitric oxide-dependent inhibition of cytochrome $c$ oxidase and adenosine triphosphate synthesis. Endocrinology 150 2569-2576. (doi:10.1210/en.2008-1342)

Received in final form 11 June 2012

Accepted 13 July 2012

Made available online as an Accepted Preprint 13 July 2012 